\title{
KMENTAENETUS, A NEW SUBGENUS OF ARISTAENETUS (HEMIPTERA: RHYPAROCHROMIDAE: LETHAEINI) FROM THE PAPUAN SUBREGION
}

\author{
Elód Kondorosy ${ }^{1,2}$, Szilvia Kovács ${ }^{1}$ and LÁszló Zsalakovics ${ }^{1}$ \\ ${ }^{1}$ University of Pannonia, Georgikon Faculty, Department of Animal Sciences \\ H-8360 Keszthely, Deák Ferenc u. 16, Hungary \\ ${ }^{2}$ Hungarian Natural History Museum, H-1088 Budapest, Baross u 13, Hungary \\ E-mails: kondorosy.ee@gmail.com, https://orcid.org/0000-0001-7162-0862, \\ szilvakovacs@gmail.com,https://orcid.org/0000-0002-6479-8088, \\ zsalakovicsl@gmail.com, https://orcid.org/0000-0002-4003-4577
}

Aristaenetus (Kmentaenetus) diabolicus Kondorosy subgen. n., sp. n. and Aristaenetus (Kmentaenetus) woodwardi Kondorosy et Zsalakovics sp. n. (Heteroptera: Rhyparochromidae: Lethaeini) from Papua New Guinea and Indonesia, are described and discussed. Comparing the general habitus of the specimens to other Lethaeini genera, they are most closely related to the genus Aristaenetus but the differences validate a new subgenus.

Keywords: Indonesia, New Guinea, Heteroptera, Lygaeoidea, new taxa.

\section{INTRODUCTION}

Lethaeini is a tribe of the family Rhyparochromidae. STÅL (1872) mentioned it first as division Lethaearia. SLATER (1964) catalogued the Lethaeini tribe with 26 genera and 111 species; later SLATER and O'Donnell (1995) with 36 genera and 156 species. Today the group includes 182 known recent species in 40 genera. Recently several researchers studied the group from various geographical regions: mostly from the Neotropical Region and Mexico (e.g. Cervantes 2012, Cervantes \& Brailovsky 2008, Dellapé \& Coscarón 2004, Dellapé et al. 2015 and O'Donnell 2007), a few from the Oriental Region (Kondorosy 2006, Li \& Bu 2006, Li et al. 2011, Zsalakovics \& Kondorosy 2014), while from the Afrotropical Region the last paper was published by Slater and O'Donnell (1999). The Pacific Region was not studied for almost 30 years. The majority of the Pacific species (21) are known from the Australian continent; only 4 Lethaeini species, all of the genus Neolethaeus Distant, 1909 are known from the Pacific islands, 3 of them from New Guinea. N. descriptus (Walker, 1872) is known from India to the Solomon Islands but not published from New Guinea. From the New Guinean species N. cheesmanae Woodward, 1968 seems to be endemic on the island, N. cantrelli Woodward, 1968 even reaches the northern part of Australia, while N. tenebrosus (Distant, 1914) is known from some Melanesian islands reaching all the way to New Caledonia. During our research we came across some specimens from eastern 
Indonesia and Papua New Guinea, which identified as belonging to two new species that are closely related to those in the genus Aristaenetus Distant, 1901 but with differences that motivated us to describe a new subgenus.

\section{MATERIAL AND METHODS}

We received the specimens from the National Museum of Prague (NMPC) and Bernice Pauahi Bishop Museum (BPBM). For the examination we used Olympus SZ-11 stereo microscope and we took the measurements with a calibrated micrometer. The specimen was photographed with a Nikon D60 digital camera with $60 \mathrm{~mm} / 2.8 \mathrm{G}$ ED AF-S Micro Nikkor objective with Meike extension tubes and Entangle 0.7.0 software and we used MicroFusion 0.7.4a for photostacking.

We follow the morphological terminology of Tsai et al. (2011) and Tsai and Rédei (2017), the nomenclature of antennal segments follows ZRZAvÝ (1990).

\section{Aristaenetus Distant, 1901}

The genus contained two species until now, A. diffinis (Walker, 1872) and A. similis Woodward et O'Donnell, 1988, both known from Australia. WoodWARD and O'DonNELL (1988) redescribed the genus in detail, therefore we will not repeat it, some additions and changes follow here.

Midline of head with micropunctures or transverse wrinkles. Clypeus convex in lateral view, always transversely rugose. Eyes without visible setae. Head diverging anteriad of eyes to antennal junction.

Anterior lobe of pronotum with sparse punctures, finer than on posterior lobe, anterolateral trichobothria sometimes absent. Sternum with impunctate, sparsely and densely punctate areas as well. Evaporative area extending on mesopleuron, forming a triangle, and as narrow line, extended to dorsal margin of metapleuron.

\section{Kmentaenetus Kondorosy subgen. $\mathrm{n}$.}

Type species: Aristaenetus (Kmentaenetus) diabolicus Kondorosy, sp. n.

Description: Body moderately elongate, punctate except of head dorsally and two spots on pronotum. Body dull, almost hairless.

Head pentagonal, dorsally and laterally impunctate, ventrally strongly transversely rugose, submedially punctate (punctures lacking around eyes, base of antennae, and anteriad of antenniferous tubercles); much longer then wide; dorsal side transversely rugose (except around and anterior to ocelli), midline relatively strongly rugose, reaching clypeus. Head everywhere with hardly visible tiny decumbent setae. Apex of clypeus acute, toothlike. Compound eyes prominent, large, postocular part longitudinally rugose, ventrally with transverse wrinkles. Ocelli at posterior margin of eyes, equidistant from eye and median. Antenniferous tubercle divergent, prominent, almost as long as eye, head almost as 
wide here as base of head. Base of head with two iridescent spots. Maxillary plates convex, smooth and shining, partly visible in dorsal view. Labium long, reaching middle of abdomen. Scape extending with half beyond apex of head. Antennae with very fine and dense decumbent pubescence and few stronger setae on scape, other segments with some fine semierect setae as well.

Lateral margin of pronotum noticeably concave, apical half narrower. Posterior part of pronotal collar densely punctate, separated from pronotum with punctate furrow, pronotum behind collar slightly elevated. Transverse furrow shallow, inconspicuous, lateral margin of pronotum hardly visible, not laminate. Midline elevated, impunctate, reaching from middle of anterior lobe almost to posterior margin. Anterior lobe of pronotum with partly impunctate but not elevated calli. Humeral angles of pronotum not rounded. Anterior margin of pronotum nearly straight, medially slightly protruding, posterior margin slightly convex. Pronotum without anterolateral trichobothria. Scutellum triangular, largely punctate, with blunt Y-carina. Clavus with four regular rows of punctures, both middle rows united anteriorly near base. Corium between veins $\mathrm{Sc}$ and $\mathrm{R}$ densely, between $\mathrm{R}$ and $\mathrm{Cu}$ shallower and sparser punctate. Costal margin slightly S-shaped, apical margin nearly straight. Membrane with two closed basal cells, 4 veins visible. Coxae finely transversely rugose, legs otherwise smooth. Profemur slightly thicker at base than in apical half, anterior margin with three small teeth apically and 5 long thin setae; other femora unarmed, with some short stronger setae only. Tibiae straight, with rows of strong stiff setae, inner side in apical half also with fine semi-decumbent pubescence (on metatibia negligible). Tarsi with very dense short fine semi-decumbent pubescence beneath. Pleura with impunctate or rugose areas between punctures, sternum impunctate and dull except ventral collar, mesothorax ventrally with medial furrow, metasternum with strong medial carina. Mesosternum limited anteriorly and posteriorly with strong arched transverse carina. Ostiolar peritreme on male directed laterad (reaching about $3 / 4$ of metapleuron), then curving posteriorly, terminating in semi-circle directed anteriad or laterad; ostiolar peritreme significantly shorter in females, directed laterally, then slightly posteriad. Evaporatorium large, reaching lateral margin of mesopleuron, occupying majority of metapleuron, almost reaching metepimeroid.

Abdomen with extremely dense micropunctures and tiny setae on ventral side. Median third of sternites III-IV smooth, lateral thirds with long transverse rugae with their lateral extremities curved posteriad submarginally. Surface of abdominal venter uneven, sternite III with median keel and with flat submedial elevation bearing trichobothria; base of sternite VI impressed sublaterally. Posterior margins of sternites III to V narrowly produced posteriorly at midline, lateral portions broadly S-shaped, curved anteriad, abruptly curved posteriad submarginally. Suture between sterna 4 and 5 curving cephalad, not reaching lateral margin; trichobothria and spiracles as usual in Lethaeini. Sternite VI of female strongly narrowed but not divided medially, together with sternite $\mathrm{V}$ medially keeled. Tergites shiny, finely rugose and extremely finely punctate transversely (wrinkles of tergite VIII stronger); posterior portions of tergite VIII and hypopleurite VIII connected by a broad, membranous cuticular area. Posterior margin of tergite VIII medially straight, laterally convex, hypopleurite VIII terminating acutely.

Male genital capsule (Fig 4D) subglobose, with fine decumbent pubescence, posterior aperture nearly rhomboidal, anterior half with two acute and a blunt teeth on each side, cuplike sclerite large, reaching about halfway of aperture, with a blunt apex medially and with sinuous arches on both sides. Paramere broad, subtriangular, inner projection very broad, terminating in a tooth orientated to base; outer projection elongate apically in a tooth (as Fig. 4A); base of blade dorsally with a strong hump (Fig. 4C). 
Spermathecal duct of female extremely long and tortuous (several times longer than body length), apical part after an oblique ring suddenly broadened to subglobular apical receptacle, significantly impressed lengthwise (Fig. 2).

Etymology - We named the new subgenus after the excellent heteropterologist Dr. Petr Kment who brought our attention to these specimens, was kind enough to loan them to us, and helped also with sending much old and new literature. The ending of the name is in reference to the genus Aristaenetus.

Remarks - This new subgenus is erected to include the two new species described in this paper. On the Eastern Hemisphere species of 9 genera of the Lethaeini have closed cells on the base of the membrane, similar to Kmentaenetus. The largest genus, Lethaeus Dallas, 1852 lacks a collar on the pronotum. Five further genera, like Neolethaeus Distant, 1909 have a convex or straight lateral margin on pronotum (lateral margin is mostly narrowly laminate). Species of two of the remaining genera with concave pronotum (Aristaenetoides Kondorosy, 2006 and Lethaeograndellus Scudder, 1962) have among others punctate head ventrally, only Aristaenetus has similar striate head ventrally as Kmentaenetus. Furthermore, Aristaenetoides has only 3 rows of punctures on clavus (contrary to 4 of Aristaenetus and Kmentaenetus). Lethaeograndellus has lamellate lateral margin of pronotum, punctate pronotal collar forming a $\mathrm{V}$, and rugose head, callar area of pronotum and abdomen, while Aristaenetus and Kmentaenetus have weakly carinate lateral margin of pronotum, impunctate and slightly arched pronotal collar, and smooth or punctate head, callar area of pronotum and abdomen.

The anterolateral trichobothria of the pronotum are often missing e.g. in Neolethaeus, as in N. cantrelli Woodward, 1968 or N. cheesmanae Woodward, 1968 (discussed by Woodward 1968), so presence or absence of the pronotal trichobothrium is not always a constant feature in a genus. One of the most unique features is the elongate and strongly curved ostiolar peritreme of the males, which is characteristic only for the species of Aristaenetus Distant, 1901 and three species of Neolethaeus: N. cantrelli, N. cheesmanae and N. descriptus Walker, 1872, and in somewhat less developed form for the American genus Bubaces Distant, 1893 (see O'DonNell 2006). Neolethaeus is not very closely related to the new species because of the different pronotum (they have lateral carina and at most slightly concave lateral margin) and shape of the paramere (Fig. 3A). So, we concluded that our species are most closely related to the genus Aristaenetus but because of the important differences we suppose it is appropriate to create a new subgenus.

O'Donnell (1991) investigated the male genitalia of most lethaeine genera, including both Aristaenetus species. The paramere of $A$. woodwardi sp. n. is unique (Fig. 3A) and similar to the paramere of $A$. similis Woodward et O'Donnell, 1988. 
The main differences between the two subgenera are that the species belonging to Aristaenetus s. str. have anterolateral trichobothria on the pronotum, however, in Kmentaenetus these are missing; also, the shape of the pronotum is different, the anterior half of the pronotum is wider in Aristaenetus s. str., while it is much more slender in Kmentaenetus species. Furthermore, Kmentaenetus species have transversely rugose heads while Aristaenetus s. str. species have punctate heads. The eye-antenna distance is in Kmentaenetus nearly as long as eye length, species, however, in Aristaenetus s. str. it is about half as long as eye length. In Kmentaenetus the eye is delimited by radial wrinkles, while in Aristaenetus s. str. the surface delimiting the eyes is smooth. Pronotal collar is impunctate in Aristaenetus s. str. and with punctures in Kmentaenetus. The pronotal humeral angles are angular or tooth-like in Kmentaenetus, not rounded as in Aristaenetus s. str. The abdomen is ventrally only sparsely punctate in Aristaenetus s. str. and not extremely densely.

\section{Aristaenetus (Kmentaenetus) diabolicus Kondorosy sp. n.}

$$
\text { (Figs 1-2) }
$$

Material examined: Holotype $\sigma^{\text {}}$ : PAPUA NG, Madang Prov. / BAITABAG, 17. v. 2011

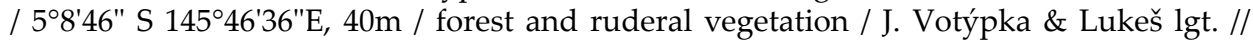
[printed with green:] Department of parasitology / Charles University in Prague / DISSECTION No. 707 / NEGATIVE (NMPC). Paratypes: same first label // [printed with red:] Department of parasitology / Charles University in Prague / DISSECTION No. 708 / POSITIVE PNG_112 (NMPC); 1 : same first label // [printed with green:] Department of parasitology / Charles University in Prague / DISSECTION No. 706 / NEGATIVE (HNHM).

Description: Body almost glabrous, on head, antennae and legs some extremely fine setae visible, on posterior antennal segments, on apical half of tibiae and on tarsi becoming longer and semierect; on inner part of pro- and mesotibiae very prominent. Clypeus shining, terminating in a sharp tooth. Labium reaching end of abdominal segment V, first segment almost reaching procoxae. Scape approximately as long as head, extending with half beyond apex of head. Humeral angles of pronotum terminating in a posteriorly curved spine. Punctures finer, row on clavus along claval furrow consisting of 35-40 punctures.

Colour: Body black, hemelytra and extremities more or less paler; labium stramineous; base of first segment and apex of fourth darker. Scape and pedicel except apex, basal $1 / 4$ of basiflagellum and distiflagellum dark brown, remaining parts slightly darker, basiflagellum in apical half stramineous; meso- and metatrochanters and basal half of meso- and metafemora also stramineous, tibiae and tarsi on two posterior pairs yellowish brown. Pronotum with 3 tiny inconspicuous basal stramineous spots: on middle and at clavi. Clavus with two stramineous lines: vein $\mathrm{AA} 1+2$ in distal 1/3, vein AA3+4 only from halfway to about three fourths of length; corium with a short line on distal fourth of vein $\mathrm{Cu}$, base of vein $\mathrm{M}$ and with two small spots: one at level of apex of scutellum between $\mathrm{R}+\mathrm{M}$ and $\mathrm{Cu}$ and one between $\mathrm{R}$ and $\mathrm{M}$ close to apical margin stramineous. A small round spot near to apical margin between veins $R$ and $M$ white. Membrane brown with slightly paler veins.

Structure: Body dull, only ventral side of head and abdomen shining. 


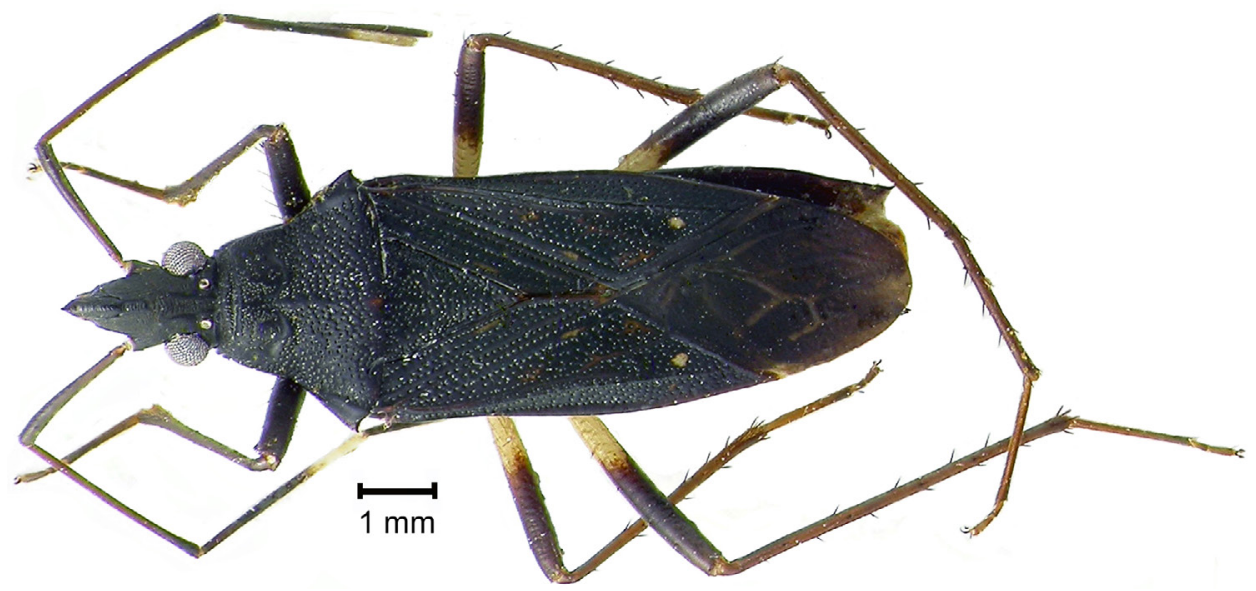

Fig. 1. Aristaenetus (Kmentaenetus) diabolicus Kondorosy holotype male, dorsal view

Distribution: Papua New Guinea.

Etymology: We named this new species after the coloration and the horn-like humeral angles on the pronotum.

Measurements (first holotype male, next 2 female paratypes) (in $\mathrm{mm}$ ): Body length: $11.18,11.56-12.06$. Head length 1.99, 2.05-2.21; width with eyes 1.60, 1.62-1.71; interocular space $0.71,0.76-0.78$; antennae 9.96, 10.14 (pedicel and next segments missing on a paratype) segment I 1.86, 1.89-1.94; II 3.15, 3.11; III 2.51, 2.64; IV 2.44, 2.45; labium 8.84, 9.34-9.36; segment I 2.46, 2.56-2.62; II 2.41, 2.54-2.61; III 2.94, 3.04-3.17; IV 1.02, 1.06-1.09. Pronotum total length 2.06, 2.17-2.23; length of anterior lobe 0.92, 0.97; width 3.36, 3.673.71; width at transverse impression 1.99, 2.07-2.09; scutellum length 1.71, 1.92-1.94; width 1.64, 1.87-1.96; claval commissure 1.09, 1.12-1.21.
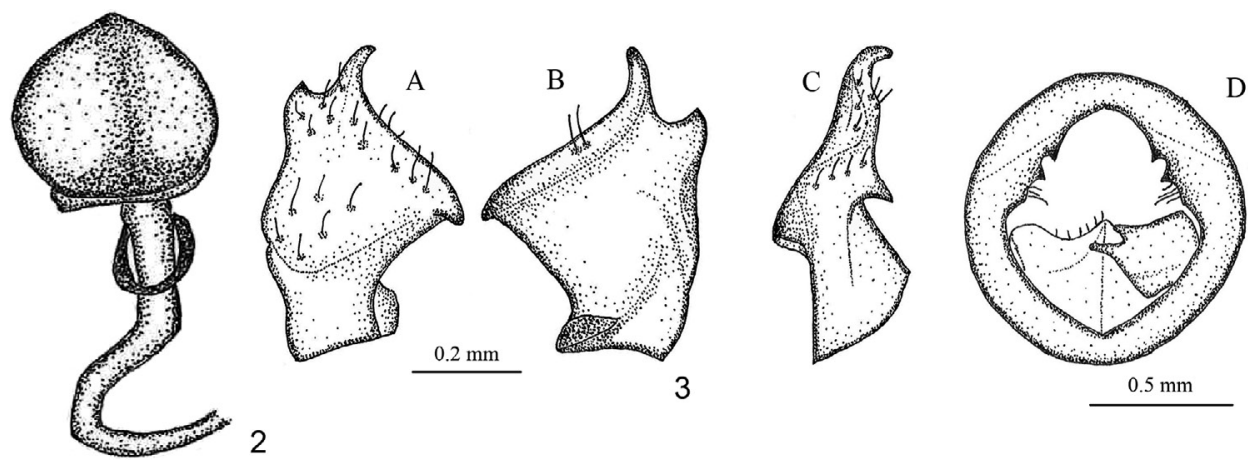

Figs 2-3. 2 = Spermatheca of A. diabolicus Kondorosy. $3=$ Male genitalia of Aristaenetus (Kmentaenetus) woodwardi Kondorosy et Zsalakovics; A-C: paramere, $\mathrm{A}=$ dorsal view, $\mathrm{B}=$ ventral view, $\mathrm{C}=$ lateral view, $\mathrm{D}=$ pygophore, dorsal view 
Remarks: These specimens were collected during an expedition of Jan Votýpka and colleagues investigating trichomonad parasites of true bugs (Smejkaloví et al. 2014). The "negative" and "positive" text of the labels means not having or having parasites in the intestine. During the investigation the genitalia were removed, sometimes partly destroyed. The male pygophore is also missing.

\section{Aristaenetus (Kmentaenetus) woodwardi Kondorosy et Zsalakovics sp. n.}

(Figs 3-4)

Material examined: Holotype $\delta^{\top}$ : Indonesia: / Ambon I. Waai / 18. [handwriting] I. 1963 // at light // A. M. R. Wegner / Collector / BISHOP Mus. (BPBM).

Description: Pubescence similar to previous species but body somewhat more pilose, visible on head and, although extremely fine, also visible on pronotum and hemelytra too. Clypeus anteriorly terminating acutely but not acuminate; maxillary plate and anteclypeus shining. Labium reaching end of fifth abdominal segment, first segment almost reaching procoxae. Scape approximately as long as head, extending with half beyond apex of head. Humeral angle of pronotum terminating angular. Punctures stronger, row on clavus along claval furrow with 30 punctures.

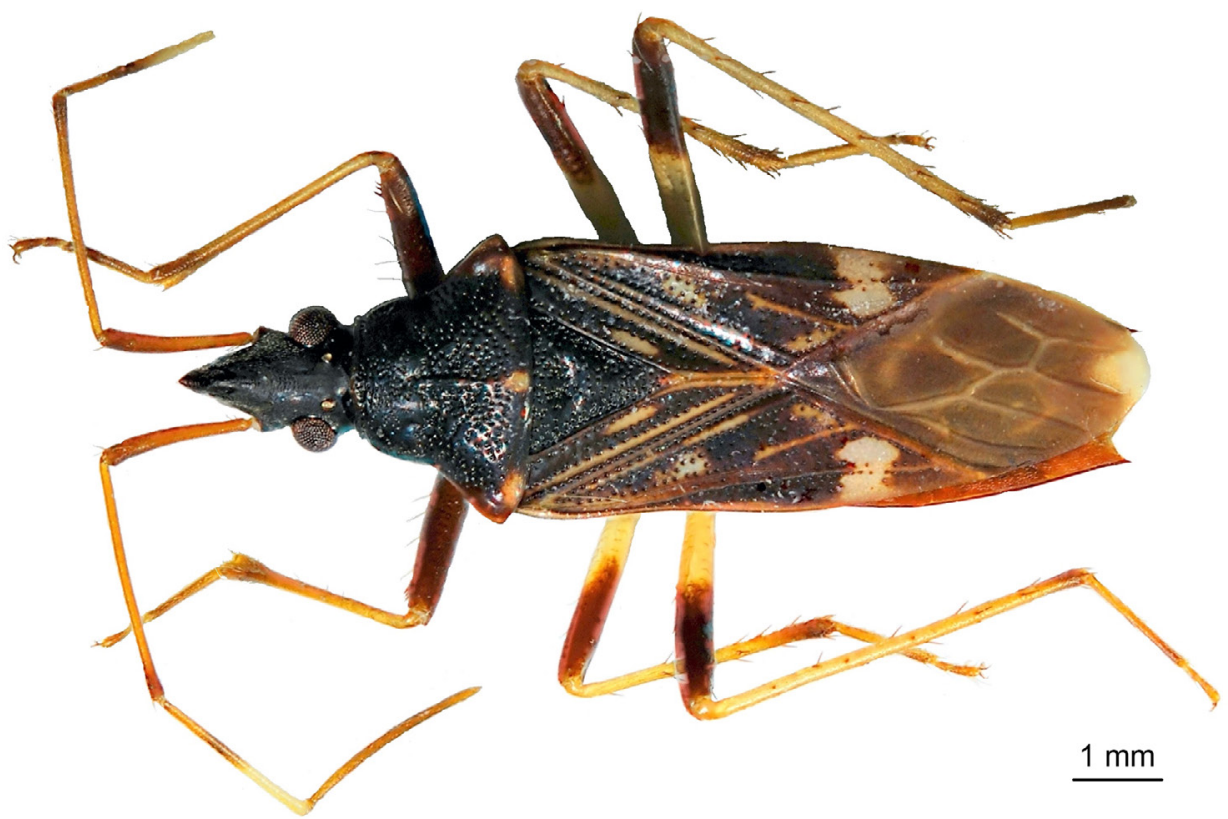

Fig. 4. Aristaenetus (Kmentaenetus) woodwardi Kondorosy et Zsalakovics holotype male, dorsal view 
Colour: Body black; humeral area of pronotum, hemelytra, dark part of legs and antenna and abdomen brown; labium stramineous with apex of fourth segment brown. Scape and pedicel except apex, and basal 1/4 of basiflagellum yellowish brown, basiflagellum in apical half stramineous with brown ring around middle; on legs trochanters, basal half of meso- and metafemora, tibiae except apex stramineous. Pronotum with 3 small basal stramineous spots: on middle and at clavi. Clavus with two stramineous lines: vein AA1+2 fully pale, vein AA3+4 only from halfway to about 3/4 of length; vein $\mathrm{Cu}$ partly, base of $\mathrm{R}+\mathrm{M}$ and vein $\mathrm{M}$ with a small spot between $\mathrm{R}$ and $\mathrm{M}$ close to apical margin also stramineous. A small spot at level of apex of scutellum between $\mathrm{R}+\mathrm{M}$ and $\mathrm{Cu}$ and a rather large transversal subapical spot forming a " $\infty$ " almost reaching end of vein $\mathrm{M}$ white. Membrane with stramineous veins and a round white spot on apex.

Structure: Head dull; pronotum, hemelytra and venter shining.

Distribution: Ambon (Indonesia, Maluku Islands).

Etymology: We named the new species in the honour of the late Thomas E. Woodward who made great discoveries regarding the Heteroptera, especially Rhyparochromidae, mostly in Lethaeini and Targaremini. He was born 100 years ago.

Measurements (in mm): Body length: 10.36. Head length: 1.91; width with eyes: 1.54; interocular space: 0.75; antenna: 8.72; I: 1.64; II: 2.58; III: 2.25; IV: 2.26; labium: 7.99; I: 2.17; II: 2.24; III: 2.50; IV: 1.08. Pronotum length: 1.95; length of anterior lobe 0.85 , width: 2.99 ; width at transverse impression 1.79, scutellum length: 1.59; width: 1.51 ; claval commissure: 0.99 .

Discussion - Aristaenetus (Kmentaenetus) woodwardi is somewhat smaller in size than $A$. (K.) diabolicus. The structure of the two new species is rather similar, the main differences are in the colouration of the hemelytra and the basiflagellum, the form of the apex of the clypeus and the humeral angle of the pronotum. Furthermore, $A$. diabolicus has much smaller punctures (outermost row of punctures of clavus contains almost 35-40 punctures, while on $A$. woodwardi only $~ 30$ ); which is good apparent on the pronotum, scutellum and hemelytra, especially on inner half of corium.

\section{Key to Aristaenetus Distant, 1901}

1 Anterolateral trichobothria on pronotum absent, collar punctate; humeral pronotal angles angular (subg. Kmentaenetus)

- Anterolateral trichobothria on pronotum present; pronotal collar impunctate, separated by a row of punctures; humeral pronotal angles rounded (subg. Aristaenetus s. str.) see Woodward \& O'DonNell (1988)

2 Body black; apex of clypeus acuminate; humeral angle acutely extending laterally, terminating in a posteriorly directed spine; punctures not very strong; hemelytra piceous with some unconspicuous small paler areas; tiny stramineous spot near apical margin of corium not reaching vein 
$\mathrm{R}$, smaller than eye; membrane nearly unicolorous brown; meso- and metatibiae brown

A. diabolicus

- $\quad$ Body black and brown; apex of clypeus acute; humeral angle bluntly extending laterally; punctures strong; hemelytra with contrasting stramineous spots; significant subapical stramineous spot of corium reaching lateral margin, bigger than eye; membrane dark brown with stramineous apex; meso- and metatibiae stramineous in apical half A. woodwardi

Acknowledgments - The authors would like to thank Petr Kment (NMPC) and James Boone (BPBM) for the loan of the material and kind help given. We are very thankful to Jane E. O'Donnell (University of Connecticut, Storrs, United States of America) and Dávid Rédei (Nankai University, Tianjin, China) for the useful comments and photos, similarly to both anonymous reviewers of the manuscript. The work is supported by the EFOP-3.6.3VEKOP-16-2017-00008 project. The project is co-financed by the European Union and the European Social Fund.

\section{REFERENCES}

Cervantes Peredo, L. \& Brailovsky, H. (2008): First record of genus Xestocoris (Hemiptera-Heteroptera: Lygaeoidea: Rhyparochromidae: Rhyparochrominae: Lethaeini) from Mexico, with description of three new species. - Annals of the Entomological Society of America 101(2): 307-313. https://doi.org/10.1603/0013-8746(2008)101[307:FRO GXH]2.0.CO;2

Cervantes Peredo, L. (2012): A new coleopteroid genus of Lethaeini (Hemiptera: Heteroptera: Lygaeoidea: Rhyparochromidae). - Proceeding of the Entomological Society of Washington 114(3): 338-346. https://doi.org/10.4289/0013-8797.114.3.338

Dellapé, P. M. \& Coscarón, M. C. (2004): New combination and new synonymy in the tribes Megalonotini and Lethaeini (Hemiptera: Rhyparochromidae). - Revista de la Sociedad Entomológica Argentina 63 (1-2): 17-18.

Dellapé, P. M., Melo, C. M. \& O'Donnell, J. E. (2015): Biodiversity and distribution of lethaeine seed bugs (Heteroptera, Rhyparochromidae, Lethaeini) from Argentina. Zoological Studies 54 (34): 1-21. https://doi.org/10.1186/s40555-015-0114-y

Kondorosy, E. (2006): A new genus of Lethaeini (Insecta: Heteroptera: Lygaeidae) from the Oriental Region. - Annalen des Naturhistorischen Museums in Wien 107B: 115-119.

LI, J.-L. \& Bu, W.-J. (2006): Three new species of Neolethaeus Distant (Hemiptera: Lygaeoidea: Rhyparochromidae: Lethaeini) from China, with a key to the Chinese species. - Zootaxa 1270: 45-56. https://doi.org/10.5281/zenodo.173247

Li, J.-L., GAO, C.-Q. \& Bu, W.-J. (2011): Review of the tribe Lethaeini Stal (Hemiptera: Heteroptera: Lygaeoidea: Rhyparochromidae) from China, with a key to Chinese genera and species. - Zootaxa 3126: 28-38. https://doi.org/10.5281/zenodo.204798

O'Donnell, J. E. (1991): A survey of male genitalia in Lethaeine genera (Heteroptera: Lygaeidae: Rhyparochrominae). - Journal of the New York Entomological Society 99: $441-470$. 
O'Donnell, J. E. (2006): A new species of Bubaces Distant (Heteroptera, Rhyparochromidae, Rhyparochrominae). - Denisia 19: 535-538.

O'Donnell, J. E. (2007): A new species of Xestocoris Van Duzee, with comments on the genus (Hemiptera: Heteroptera: Rhyparochromidae: Rhyparochrominae). - Zootaxa 1606: 51-57. https://doi.org/10.11646/zootaxa.1606.1.4

SLATER, J. A. (1964): A catalogue of Lygaeidae of the World. Vol. 2. - University of Connecticut, Storrs, $1668 \mathrm{pp}$.

Slater, J. A. \& O'Donnell, J. E. (1995): A catalogue of the Lygaeidae of the World (1960-1994). - New York Entomological Society, New York, 410 pp.

Slater, J. A. \& O'Donnell, J. E. (1999): New species of Lethaeini from Madagascar (Heteroptera: Lygaeoidea: Rhyparochromidae). - Journal of the New York Entomological Society 107: 256-267.

Smejkalová, P., VotÝPKA, J., Lukeš, J. \& ČEPIČKA, I. (2014): First report on trichomonads from true bugs. - Folia Parasitologica 61: 189-194. https://doi.org/10.14411/fp.2014.025

STÅL, C. (1872): Genera Lygaeidarum Europae disposuit. - Öfversigt af Kongliga VetenskapsAkademiens Förhandlingar 29: 37-62.

Tsai, J.-F. \& RÉdeI, D. (2017): The genus Arocatus in Taiwan (Hemiptera: Heteroptera: Lygaeidae). - Zootaxa 4299(2): 238-252. https://doi.org/10.11646/zootaxa.4299.2.4

Tsai, J.-F., RéDeI, D., YeH, G.-F. \& YANG, M.-M. (2011): Jewel bugs of Taiwan (Heteroptera: Scutelleridae). - National Chung Hsing University, Taichung, 309 pp.

Woodward, T. E. (1968): A new species-pair of Neolethaeus Distant (Hemiptera: Lygaeidae) from Northern Queensland and New Guinea. - Proceedings of the Royal Society of Queensland 80(4): 35-42.

Woodward, T. E. \& O'Donnell, J. E. (1988): The genus Aristaenetus Distant (Hemiptera: Lygaeidae: Rhyparochrominae) with the description of a new species. - Memoirs of the Queensland Museum 25(2): 481-491.

Zrzavý, J. (1990): Evolution in antennal sclerites in Heteroptera (Insecta). - Acta Universitatis Carolinae Biologica 34: 189-227.

Zsalakovics, L. \& Kondorosy, E. (2014): Margolethaeus, a new Lethaeini genus (Hemiptera: Rhyparochromidae) from the Oriental Region. - Acta Zoologica Academiae Scientiarum Hungariae 60(4): 307-312.

Received September 9, 2018, accepted December 16, 2018, published March 18, 2019 